\title{
Moderasi Pemikiran Fikih Hubungan Antarumat Beragama di Majelis Tarjih dan Tajdid Muhammadiyah
}

\author{
Ahwan Fanani \\ UIN Walisongo, Semarang
}

\begin{abstract}
Muhammadiyah is credited as moderate islamic organization due to its long and familiar encounter with national and social issues in Indonesia. The question on how Muhammadiyah position on the issues of religious relationship and on how Muhammadiyah formulates its view on the issue lead to the question on religious opinion produced by official body of Muhammadiyah that is in charge to give answer. The formulation of Muhammadiyah's stance related to the relationship between moslems and nonmoslems is under authority of Majelis Tarjih and Tajdid (MTT), formal board in Muhammadiyah issuing fatwas or religious opinions related to religious and social problems faced by Muhammadiyah's members. From this board's decisions, the official stance of Muhammadiyah can be analyzed using the spectacle of moderatism. Muhammadyah has two different stances in dealing with religious issues. It has clear and relatively strict position on akida (belief) and ibada (ritual) but it has loose and open position in muamala (daily relationship) to other people. However, Muhammadiyah develops broader approach in understanding Islamic text and accepting more diverse legal sources, such as sadd dzariah and maslahah. In sum, the stance of Muhammadiyah to the relationship between moslems with other religious people will be influenced by the division between akida-ibada and muamalah aspects, which it will be more flexible to the later. This divison enables it to develop more moderat view or legal opinion related to the relationship between moslems and other religious people.
\end{abstract}

\begin{abstract}
Abstrak
Muhammadiyah dianggap sebagai organisasi Islam moderat karena perjalanan panjang dan akrab dengan isu-isu nasional dan sosial di Indonesia. Pertanyaan tentang bagaimana posisi Muhammadiyah pada isu-isu hubungan agama dan bagaimana Muhammadiyah merumuskan pandangannya pada masalah, menyebabkan pertanyaan pada pendapat religius yang dihasilkan oleh badan resmi Muhammadiyah yang bertugas untuk memberikan jawaban. Perumusan sikap Muhammadiyah yang berkaitan dengan hubungan antara umat Islam dan nonmuslim berada di bawah kewenangan Majelis Tarjih dan Tajdid (MTT), papan formal dalam Muhammadiyah mengeluarkan fatwa atau pendapat agama yang berkaitan dengan masalah agama dan sosial yang dihadapi oleh anggota Muhammadiyah. Dari keputusan ini board, sikap
\end{abstract}


resmi Muhammadiyah dapat dianalisis menggunakan tontonan moderatism. Muhammadiyah memiliki dua sikap yang berbeda dalam menangani isu-isu agama. Ini memiliki posisi yang jelas dan relatif ketat pada akida (keyakinan) dan ibada (ritual) tetapi memiliki posisi longgar dan terbuka di muamala (hubungan setiap hari) untuk orang lain. Namun, Muhammadiyah mengembangkan pendekatan yang lebih luas dalam memahami teks Islam dan menerima sumber hukum yang lebih beragam, seperti sadd dzariah dan maslahah. Singkatnya, sikap Muhammadiyah terhadap hubungan antara umat Islam dengan umat beragama lain akan dipengaruhi oleh pembagian antara akida-ibada dan muamalah, aspek yang nantinya akan lebih fleksibel. Divisi ini memungkinkan untuk mengembangkan lebih pandangan moderat atau pendapat hukum yang terkait dengan hubungan antara umat Islam dan umat beragama lainnya.

Keywords: moderat, fiqh, relationship between religious people, Muhammadiyah DOI: 10.22515/shahih.v2i1.705

\section{Pendahuluan}

Islam di Indonesia merupakan pertemuan dari berbagai tradisi pemikiran dengan ciri khas masing-masing. Keanekaragaman pemikiran Islam di Indonesia memberikan warna bagi keanekaragaman bangsa Indonesia, selain keanekaragaman agama, budaya, dan bahasa. Pemikiran Islam di Indonesia merentang dari upaya mempribumisasikan Islam, purifikasi kehidupan keagaman intra umat Islam, sampai pada upaya untuk menjadikan Islam di Indonesia bagian dari kekuasaan politik Islam internasional. Keanekaragaman pemikiran Islam tersebut di satu sisi memberikan kekayaan wajah Islam di Indonesia, dan di sisi lain membawa tantangan untuk hidup berkoeksistensi secara damai, baik dalam konteks kehidupan bernegara dan berbangsa maupun dalam konteks kehidupan bermasyarakat.

Nilai positif dari Islam di Indonesia adalah adanya dukungan yang kuat terhadap gagasan negara dan bangsa Indonesia. Para perumus dasar negara Pancasila (Tim Sembilan) sebagian juga berasal dari kalangan tokoh-tokoh Islam, seperti K.H. Wahid Hasyim (NU), K.H. Kahar Muzakir (Muammadiyah), Abikusno Tjokrosuyoso (Sarekat Islam), dan K.H. Agus Salim (Sarekat Islam). Hal itu menunjukkan peran aktif umat Islam dalam upaya untuk mencari common ground bagi kehidupan kebangsaan dan kebhinekaan bangsa Indonesia. Tidak mengherankan apabila pendefinisian mengenai kebangsaan dan kebhinekaan tidak bisa lepas dari peran para tokoh umat Islam, termasuk ketika negara dalam keadaan genting. Pada era Reformasi, para tokoh umat Islam juga turut berperan untuk mengawal transisi Reformasi sehingga tidak mengherankan apabila proses demokratisasi di Indonesia pada era Reformasi mendapatkan dukungan langsung dari para tokoh organisasi Islam di Indonesia, seperti KH Abdurrahman Wahid (NU), Amien Rais (Muhammadiyah), dan Nurcholish Madjid. 
Meskipun kontribusi umat Islam dalam pembangunan negara sangatlah besar, namun salah satu ancaman terhadap kebangsaan tersebut tidak bisa dipungkiri lahir dari rahim gerakan Islam juga. Sebagian gerakan Islam menjadi ancaman bagi kebangsaan dan kebhinekaan karena ideologi dan pendekatan dakwah yang konfrontatif, bahkan mengesahkan penggunaan kekerasan. Dalam konteks tersebut, dukungan umat Islam di Indonesia terhadap kebangsaan dan kebhinekaan seolah terkurangi oleh aktivitas dakwah yang tidak tepat empan dan papan-nya tersebut. Negara Indonesia yang diatur oleh UndangUndang dengan pemerintah yang masih mampu memelihara ketertiban, dipandang sebagai ajang peperangan global terhadap musuh yang dipandang juga melancarkan perang global. Akibatnya adalah lahirnya gagasan untuk memberlakukan hukum-hukum peperangan di Indonesia yang mengakibatkan aksi-aksi kekerasan dan terorisme dan aksi-aksi anarkis terhadap hal-hal yang dipandang sebagai "ancaman" bagi agama.

Respon umat Islam terhadap realitas-realitas sosial, politik, maupun kebudayaan tersebut ditentukan oleh penafsiran terhadap ajaran agama. Secara spesifik, penafsiran terhadap ajaran agama yang terkait dengan perilaku dan tindakan manusia tercakup dalam fikih. Kekerasan berbasis agama, yang sebagian lahir dari pemahaman fikih, muncul dari logika keterancaman Islam dan keabsahan membela diri terhadap apa yang didefinisikan sebagai ancaman terhadap agama yang dihasilkan melalui istinbath hukum Islam. Hal itulah yang diungkapkan oleh Muhammad Imarah ketika ia membela fundamentalisme agama (Islam). Ia berpendapat bahwa apa yang disebut sebagai fundamentalisme agama oleh orang Barat tidak lebih sebagai para ulama yang melakukan istinbath hukum, sebagaimana laiknya ulama yang lain (Imarah, 1988, p. 26). Hal itu menunjukkan bahwa fikih bisa memberikan kontribusi bagi pemahaman agama yang radikal, yang kontraproduktif dengan upaya untuk penciptaan kehidupan sosial yang damai dan rukun.

Dalam konteks itulah barangkali muncul gagasan mengenai perlunya fikih moderat. Fikih moderat adalah pemahaman fikih yang sesuai dengan konteks sosial masyarakat Indonesia dan mendukung damai hubungan antarumat beragama. Tidak mudah memang untuk merumuskan secara tegas batasan fikih moderat. Apakah ia adalah fikih yang sejalan dengan kepentingan rukun dan damai dalam konteks berkebangsaan dan sosial ataukah ia fikih yang didasarkan atas jalan tengah antara kecenderungan radikal dan kecenderungan apatis di kalangan umat Islam terhadap isu-isu sosial, politik, dan kebudayaan yang dihadapi umat Islam. Acuan yang jelas dari fikih moderat barangkali adalah Alquran surah Al-Baqarah ayat 143 yang menyatakan bahwa umat Islam dijadikan sebagai umat wasath (moderat/adil). Wasath berarti berada pada posisi tengah, tidak berlebihan dan tidak lalai atau abai sehingga bisa menjadi yang terbaik (Al-Baghawi, 2002, p. 69).

Muhammadiyah sering dikategorikan sebagai organisasi yang berorientasi kemodernan dan moderat. Namun, pada batas tertentu memiliki latar belakang puritan. 
Dua kecenderungan yang tampak kontradiktif itu menarik untuk dilihat dalam konteks fikih hubungan antarumat beragama. Sikap terhadap hubungan tersebut ditentukan oleh cara pandang keagamaan, khususnya produk hukum yang dilahirkan oleh lembaga resmi, yaitu Majelis Tarjih dan Tajdid. Produk hukum itu sendiri tidak bisa dilepaskan dari pendekatan dan metode dalam melakukan istinbath (penggalian hukum) karena keluwesan produk hukum dipengaruhi oleh cara bagaimana hukum Islam itu dipahami.

Tulisan ini adalah upaya untuk melihat moderasi yang ada dalam putusan hukum Majelis Tarjih dan Tajdid (MTT) Muhammadiyah dan metode yang dipergunakan dalam proses istinbath tersebut. Jadi, tulisan ini bertujuan untuk memotret fikih moderat Muhammadiyah dalam hubungan antarumat beragama dari aspek metodologis dan aspek putusan Majelis Tarjih dan Tajdid, baik di level nasional maupun Jawa Tengah, dalam kasus-kasus hubungan antarumat beragama.

\section{Posisi Majelis Tarjih dan Tajdid}

Sejak awal berdirinya, Muhammadiyah memiliki tiga perhatian utama, yang menjadi basis kultur Muhammadiyah sampai saat ini, yaitu pendidikan, hal-hal keagamaan, dan sosial. Pertama, Muhammadiyah lahir dari upaya modernisasi kehidupan sosial. Upaya modernisasi tersebut sejak awal dilakukan oleh KH Ahmad Dahlan, dalam bidang pendidikan, kesehatan, dan sosial. Modernisasi dalam bidang pendidikan terjadi melalui pengajaran ilmu dan metode umum di sekolah agama dan pendidikan agama di sekolah umum, seperti yang diujicobakan oleh KH Ahmad Dahlan di sekolah pemerintah Belanda saat itu. Modernisasi sosial tercermin melalui pengembangan layanan sosial (panti asuhan) dan dorongan kaum perempuan untuk bersekolah di sekolah umum. Pelayanan kesehatan tercermin dari rumah sakit dan balai kesehatan yang didirikan oleh organisasi Muhammadiyah.

Kedua, kecenderungan pertama itu kemudian bersinergi dengan kecenderungan kedua, yaitu persoalan keagamaan umat Islam. Gerakan Muhammadiyah tidak bisa dilepaskan dari kekhawatiran terhadap gerakan missi dari agama lain yang dipandang memengaruhi keagamaan umat Islam (Shihab, 1998). Oleh karena itu, Muhammadiyah sangat sensitif terhadap isu-isu hubungan antarumat beragama. Namun, dalam sejarahnya sensitivitas itu diekspresikan dalam bentuk kompetisi, yang tercermin dalam pengembangan infrastruktur pendidikan, kesehatan, dan sosial, dan tidak terekspresi dalam tindakan kekerasan fisik. Muhammadiyah sendiri tidak menolak kerjasama dengan umat agama lain dalam penciptaan kemaslahatan sosial, sebagaimana dinyatakan dalam Kongres Tahun 1936. Sikap Muhammadiyah terhadap umat agama lain, menurut Kongres Tahun 1936 adalah menyeru agar mereka kembali ke tauhid dan menghormati nabi-nabi serta bekerjasama (membantu) amalan Muhammadiyah yang hasilnya bermanfaat bagi masyarakat bangsa yang beragama 
apapun (Diklitbang, 2010, pp. 98-99).

Ketiga, kecenderungan lain yang berkembang di kalangan warga Muhammadiyah kemudian adalah purifikasi agama. Purifikasi agama tersebut lahir dari dua pengaruh: 1) pengaruh gagasan modernisme yang mengutamakan rasionalisme, sebagaimana dikembangkan oleh Muhammad Abduh, yang mendorong pemikiran keagamaan lebih akomodatif terhadap modernitas dan 2) pengaruh purifikasi agama, sebagaimana dikembangkan oleh Ibnu Taimiyyah, yang menekankan legitimasi agama terhadap praktik peribadatan dan ritual.

Pengejawantahan pemikiran keagamaan Muhammadiyah terletak pada organ yang menangani persoalan hukum dan pemikiran agama, yaitu Majelis Tarjih dan Tajdid (MTT). Muhammadiyah adalah organisasi keagamaan dengan penekanan kuat terhadap otoritas legal rasional (otoritas yang lahir dari sistem organisasi) sehingga representasi resmi Muhammadiyah adalah keputusan Majelis Tarjih dan Tajdid.

Majelis Tarjih dan Tajdid sendiri lahir darigagasan salah seorang tokoh Muhammadiyah, yang juga menjadi salah satu empat serangkai dalam perjuangan kemerdekaan bersama Soekarno, Hatta, dan Ki Hajar Dewantoro yaitu KH Mas Mansur. Kiai Haji Mas Mansur melihat perlunya Muhammadiyah memiliki lembaga yang menangani bidang agama, untuk menyelesaikan pertikaian pemahaman agama di kalangan warga Muhammadiyah. Majelis Tarjih berdiri pada Kongres Muhammadiyah XVII Tahun 1928 di Pekalongan. Nama Majelis Tarjih sempat mengalami beberapa perubahan, yaitu Majelis Tarjih dan Pengembangan Pemikiran Islam (MTPPI) pada Muktamar ke-43 di Banda Aceh Tahun 1995 dan berubah lagi menjadi Majelis Tarjih dan Tajdid pada Muktamar ke-45 di Malang Tahun 2005 (Hidayat dkk, 2010, p. 102).

Majelis Tarjih dan Tajdid inilah yang menjadi organ resmi organisasi yang melahirkan fatwa atau keputusan hukum yang menjadi rujukan warga Muhammadiyah. Di antara tugas dan fungsi MTT adalah:

1. Membimbing umat, memberikan arah, menyampaikan fatwa keagamaan dan memberikan sesuatu dasar pembenaran keagamaan yang dapat dipahami umat dalam suatu konsep yang terpublikasi secara terencana dan meluas agar masalah dan tantangan yang tumbuh bisa dimengerti dan dijawab dengan semangat rahmat lil 'alamin.

2. Mempergiat pengkajian dan penelitian ajaran Islam dalam rangka mengembangkan ciri pelaksanaan tajdid dan mengantisipasi perkembangan yang tumbuh dalam masyarakat (Hidayat dkk, 2010, pp. 102-103). Oleh karena itu, menjadi tugas dan fungsi MTT untuk memberikan pemahaman kepada umat Islam, khususnya warga Muhammadiyah, mengenai aspek-aspek keagamaan termasuk pentingnya pengembangan fikih moderat. Pemahaman terhadap potensi pengembangan fikih moderat tersebut dapat dilihat dari 
aspek metodologis maupun aspek produk hukum. Sesuai dengan tema penelitian ini "Membangun Kembali Fikih Moderat untuk Mengharmoniskan Hubungan antarumat Beragama dan Intern Umat Islam”, maka bahasan dalam makalah ini diarahkan untuk mencari instrumen untuk pembangunan fikih moderat tersebut. Instrumen dalam konteks hukum Islam terletak kepada aspek metodologis, yang juga telah menjadi perhatian besar di kalangan para pakar hukum Islam.

\section{Modal Metodologis}

Pengembangan fikih yang moderat tidak dapat dilepaskan dari aspek metodologis, yaitu metode untuk istinbath hukum. Tanpa metode istinbath yang memadai akan sulit dirumuskan sebuah hukum yang sejalan dengan perkembangan zaman dan kontekstual. Dalam tubuh MTT persoalan metodologis ini mendapatkan perhatian dan mengalami perkembangan sejalan dengan perkembangan tantangan umat.

Acuan metodologis MTT dalam menjawab berbagai persoalan hukum Islam adalah Manhaj Tarjih. Manhaj Tarjih tersebut dapat ditemukan dalam Himpunan Putusan Tarjih maupun hasil Munas Tarjih. Himpunan Putusan Tarjih (HPT) sebagai produk resmi Majelis Tarjih Muhammadiyah mengandung berbagai fatwa hukum, sekaligus manhaj untuk melakukan tarjih. Awalnya, bahasan ushul fiqh di HPT lebih menekankan kepada aspek pemahaman hadis, yaitu: a) posisi hadis mauquf, b) posisi hadis mursal tabii dan shahabi, c) posisi hadis dlaif yang saling menguatkan, d) persoalah jarh dan tadlis, dan e) pemahaman sahabat terhadap hadis musytarak (Muhammadiyah, 2011, p. 302).

Manhaj Tarjih dalam HPT tersebut menekankan tentang bagaimana penerimaan hadis dan pemahaman hadis oleh sahabat. Dalam konteks itu, Manhaj Tarjih seolah menempatkan Majelis Tarjih dalam asas pemikiran ahl al-hadis. Namun, sebenarnya penekanan terhadap aspek pemahaman hadis lahir dari upaya untuk mengakses langsung sumber-sumber hukum Islam, khususnya hadis. Persoalan-persoalan hadis di atas umum menjadi pembahasan dalam kitab-kitab ushul fiqh. Pembahasan mengenai hadis mursal dan sifat rawi telah menjadi bagian tidak terpisahkan dalam ushul fiqh klasik (Al-Syafii, 2010, pp. 79-81). Pendekatan ini kemudian menjadi model utama Majelis Tarjih dalam menjawab masalah-masalah hukum umat Islam.

Sudah barang tentu pemahaman hadis sebagai pilar manhaj masih memerlukan dukungan dari metode yang lain. Hal itu disadari oleh berbagai elemen di Muhammadiyah. Di tingkat wilayah Jawa, misalnya, MTT PW Muhammadiyah Jawa Tengah dalam Musyawarah Wilayah (Musywil) di Klaten tanggal 30-31 Mei 1995, merekomendasikan penyempurnaan pokok-pokok Manhaj Tarjih, dengan penggunaan 1) ulum al-hadis, 2) ushul fiqh, dan 3) ulum al-tafsir (Tengah, 2010, pp. 189-190). Musywil Klaten juga mengusulkan 
agar penyempurnaan Manhaj Tarjih tersebut dilakukan dengan memperhatikan berbagai pendapat mutakhir tentang ketiga hal tersebut.

Rekomendasi Musywil Tarjih PW Muhammadiyah Jawa Tengah tahun 1995 tersebut mencerminkan sebuah kesadaran di kalangan ulama Muhammadiyah terhadap arti penting pengembangan aspek metodologis dalam tarjih. Rekomendasi tersebut merupakan upaya untuk mendorong penyempurnaan Manhaj Tarjih yang ada karena kebutuhan terhadap aspek metodologi dalam beristinbath hukum sangat jelas. Sembilan tahun sebelumnya, Musywil di tempat yang sama, Klaten, juga merekomendasikan perbaikan pokok-pokok Manhaj Tarjih di bawah judul "Ushul Fiqh". Selain perbaikan redaksional terhadap pokok-pokok Manhaj Tarjih yang telah ada, Musywil juga membahas mengenai posisi 'urf (adat) dalam hukum Islam. Musywil Klaten Tahun 1986 menyatakan:

1. 'Urf (adat) dalam bidang muamalah dapat memiliki kekuatan hukum syar'i.

2. 'Urf (adat) yang dimaksud dalam nomor 1, dengan syarat tidak bertentangan dengan jiwa syariat (maqashidusysyariah).

3. Nash yang berdasarkan 'urf, penafsirannya dapat berubah dengan perubahan 'urf itu sendiri (Tengah, 2010, p. 1905). Putusan Musywil Tarjih Klaten Tahun 1986 tersebut merupakan terobosan besar di lingkungan Muhammadiyah sendiri. 'Urf (adat) yang selama ini menjadi persoalan di kalangan warga Muhammadiyah, utamanya dalam kaitannya dengan aspek religi dan keyakinan yang melandasi berbagai adat di masyarakat, secara metodologis mendapatkan pengakuan dari Majelis Tarjih PW Jawa Tengah. Tentu saja, pengakuan itu tetap berada dalam bingkai keyakinan Muhammadiyah mengenai pemurnian keyakinan Islam dalam konteks sosial dan kebudayaan. Setidaknya, secara metodologis telah terbangun instrumen bagi Majelis Tarjih untuk mengapresiasi 'urf yang relevan dan sejalan dengan nilai dasar keislaman. Pembahasan mengenai 'urf dalam penyempurnaan Manhaj Tarjih tersebut menjadi bagian dari arus gerakan nasional MTT Muhammadiyah untuk melakukan penyempurnaan Manhaj Tarjih. Munas Tarjih Jakarta XXV 2005 secara jelas memasukkan 'urf sebagai salah satu teknik untuk istinbath hukum.

Sebelum Munas XXV Tahun 2005, upaya untuk melakukan rekonstruksi Manhaj Tarjih telah dilakukan. Majelis Tarjih PP Muhammadiyah periode 1985-1990 melakukan upaya rekonstruksi Manhaj Tarjih pada tahun 1986. Hasil rekonstruksi, yang kemudian dikirim ke seluruh wilayah Muhammadiyah itu berisi hal-hal berikut (Abdurrahman, 2004, pp. 12-14):

1. Dalam beristinbath, dasar utamanya adalah Alquran dan sunah. Ijtihad atau istinbath atas dasar illah terhadap hal-hal yang tidak terdapat di dalam nash dapat dilakukan sepanjang tidak menyangkut bidang ta'abbudi.

2. Dalam memutuskan keputusan dilakukan secara musyawarah (ijtihad jama’i)

3. Tidak mengikatkan diri kepada suatu mazhab, tetapi pendapat imam-imam mazhab 
dapat menjadi pertimbangan sepanjang sesuai dengan jiwa Alquran dan sunah

4. Berprinsip terbuka dan toleran dan tidak beranggapan bahwa hanya keputusan Majelis Tarjih yang paling benar.

5. Dalam masalah akidah (tauhid) hanya dipergunakan dalil-dalil mutawatir.

6. Tidak menolak ijma' sahabat sebagai dasar keputusan

7. Terhadap dalil-dalil yang tampak mengandung ta'arud (pertentangan), digunakan cara al-jam' wa al-tawfiq. Kalau tidak bisa baru ditarjih.

8. Menggunakan asas al-sadd al-zarai' untuk menghindari fitnah dan mafsadah.

9. Menta'lil dapat dipergunakan untuk memahami kandungan dalil-dalil Alquran dan alsunnah sepanjang sesuai dengan tujuan syariat.

10. Penggunaan dalil-dalil untuk menetapkan sesuatu hukum dilakukan secara komprehensif, utuh dan bulat. Tidak terpisah.

11. Dalil-dalil umum Alquran dapat ditakhsis dengan hadis ahad, kecuali dalam bidang akidah.

12. Dalam mengamalkan agama Islam, menggunakan prinsip taysir.

13. Dalam bidang ibadah yang diperoleh ketentuan-ketentuannya dari Alquran dan sunah, pemahamannya dapat dengan menggunakan akal, sepanjang diketahui latar belakang dan tujuannya

14. Dalam hal-hal yang termasuk dalam al-umur al-dunyawiyah, yang tidak termasuk tugas Nabi, penggunaan akal sangat diperlukan untuk tercapainya kemaslahatan umat.

15. Untuk memahami nash yang musytarak, paham sahabat dapat diterima.

16. Dalam memahami nash, makna dzahir didahulukan dari takwil dalam bidang akidah, dan takwil sahabat dalam hal itu tidak harus diterima.

Rekonstruksi tersebut menegaskan bahwa pembahasan metodologis semakin menempati posisi penting dalam Manhaj Tarjih. Rekonstruksi Manhaj Tarjih di atas memasukkan berbagai tema ushul fiqh yang penting dalam proses istinbath hukum yaitu: 1) ijma' sahabat, 2) qiyas, 3) sadd zariah, 4) penyelesaian ta'arud al-adillah melalui jam' wa altaufiq dan takhsis, 5) pemahaman kaidah lughawiyah, khususnya nash yang musytarak dan pemahaman sahabat, 6) prioritas makna dzahir dibandingkan makna takwil, dalam perkara akidah, 7) ijtihad jamai, dan 8) penggunaan akal dalam masalah ibadah meskipun qiyas illat dalam masalah ubudiyah masih ditolak dan dalam masalah muamalah. Rekonstruksi tersebut juga membuka pintu bagi penggunaan sumber-sumber mazhab, meskipun tidak mengikatkan diri dengan mazhab.

Dengan bekal tersebut, para ulama tarjih menjadi semakin leluasa untuk melakukan istinbath dan sekaligus lebih jelas manhaj yang bisa mereka jadikan pedoman. Meskipun pemahaman nash Alquran dan hadis masih menjadi prioritas utama, namun logika-logika ushul fiqh semakin banyak digunakan dalam Musywil-Musywil Tarjih. Kaidah-kaidah ushul 
fiqh semakin sering dijadikan argumentasi dalam perdebatan hukum para peserta Musywil Tarjih, bahkan kaidah-kaidah fikih sebagai kaidah istinbath dalam bidang furu'-pun semakin sering digunakan.

Momentum besar bagi peletakan Manhaj Tarjih yang lebih kontekstual muncul Musyawarah Nasional (Munas) Tarjih XXIV di Malang Tahun 2000 yang diikuti dengan Munas Tarjih XXV di Jakarta Tahun 2005. Kedua Munas tersebut membahas isu penting mengenai pendekatan bayani, burhani, dan irfani yang sedang mengemuka. Berbagai hal masih menjadi hambatan bagi pembahasan Manhaj pada Munas Tarjih XXIV di Malang, khususnya mengenai pendekatan irfani. Akan tetapi, Munas Tarjih XXV di Jakarta menghasilkan keputusan yang lebih jelas.

Pada Bab II Putusan Munas Jakarta disebutkan dengan jelas bahwa pertama, sumber ajaran Islam adalah Alquran dan sunah yang maqbulah. Kedua, pemahaman terhadap kedua sumber tersebut dilakukan secara komprehensif-integralistik dengan melalui pendekatan bayani, burhani, dan irfani dalam suatu hubungan yang bersifat spiral ("Manhaj Tarjih Muhammadiyah," 2014). Dengan demikian, hambatan terhadap pendekatan irfani telah diselesaikan dan pendekatan irfani diterima sebagai pendekatan terhadap sumber hukum secara sinergis dengan bayani dan burhani.

Munas Tarjih XXV Tahun 2005 di Jakarta juga melakukan sistematisasi mengenai metode, pendekatan, dan teknik istinbath terhadap kasus-kasus hukum yang ditunjuk oleh nash secara dzanni dan kasus-kasus yang belum mendapatkan jawaban hukum. Sistematisasi ketiga hal tersebut adalah sebagai berikut:

1. Metode ijtihad: bayani, ta'lili, dan istislahi.

2. Pendekatan ijtihad: tafsir al-ijtima'i al-mu'ashir (hermeneutik), at-tarikhi (historis), assusuluji (sosiologis), dan al-antrubuluji (antropologis).

3. Teknik: ijma', qiyas, masalih mursalah, dan 'urf.

Munas Tarjih XXV Jakarta juga melahirkan keputusan yang lebih tegas mengenai penyelesaian taa'rud adillah, tarjih nash hadis, dan kaidah-kaidah memahami hadis.

Meskipun hasil Munas Tarjih XXV Jakarta tersebut masih memerlukan uraian, penjabaran, dan sosialisasi lebih lanjut, setidaknya Majelis Tarjih Muhammadiyah Pusat telah meletakkan sebuah paradigma, pendekatan, dan metode istinbath hukum yang potensial untuk menjawab persoalan-persoalan sosial-keagamaan saat secara kontekstual. Secara normatif, Majelis Tarjih memiliki landasan yang kuat dan cukup komprehensif dalam menjawab persoalan-persoalan umat. Hanya saja, pelaksanaan dan aplikasinya sangat ditentukan oleh dinamika dan tingkat pemahaman para ulama Muhammadiyah sendiri.

Setidaknya, dalam perdebatan-perdebatan hukum dalam Musywil yang penulis ikuti, acuan kepada Manhaj Tarjih tersebut, seperti al-jam' wa al-taufiq dalam dan kaidah-kaidah 
fikih, semakin akrab di kalangan ulama Muhammadiyah. Hal itu membuka pintu lebih luas bagi pengembangan fikih moderat di kalangan Muhammadiyah karena manhaj yang secara eksplisit memberikan ruang bagi pendekatan sosiologis, antropologis, dan hermeneutis lebih potensial untuk melahirkan fatwa-fatwa yang lebih moderat.

\section{Menuju Moderasi}

Moderasi dalam pemikiran hukum Islam melahirkan fikih moderat, yang ketika diterapkan pada ranah hubungan antarumat beragama dapat membangun hubungan harmonis antarumat beragama. Fikih demikian sebenarnya bukan hal baru dalam tradisi hukum Islam. Kebutuhan fikih moderat tidak bisa dilepaskan dari kebutuhan umat Islam dan membangun kehidupan berbangsa dan bernegara. Tantangan Indonesia adalah problem intoleransi, kekerasan, dan konflik yang di antaranya menggunakan simbol dan legitimasi agama.

Bagi Muhammadiyah, keberadaan negara dan bangsa Indonesia adalah bagian tidak terpisahkan dari sejarah perkembangan Muhammadiyah sendiri. Meskipun Muhammadiyah lahir sebelum Indonesia lahir, namun Muhammadiyah bersama dengan umat Islam dan umat agama lain juga turut berjuang bagi kelahiran dan tegaknya bangsa dan negara. Bukti dari keterlibatan warga Muhammadiyah tersebut terlihat dari sumbangsih warga Muhammadiyah dalam gerakan kebangsaan. Jenderal Angkatan Bersenjata pertama RI adalah aktivis Pandu Muhammadiyah (Jenderal Soedirman), ketua KNIP pertama, yaitu Kasman Singodimejo, adalah tokoh Muhammadiyah, demikian pula dengan Presiden pertama RI, Soekarno, adalah guru sekolah Muhammadiyah dan pengurus Majelis Pendidikan Muhammadiyah ketika di buang ke Bengkulu.

Di sisi lain, warga Muhammadiyah memiliki sikap tegas terhadap masalah-masalah yang dikategorikan sebagai wilayah akidah (keyakinan) dan ubudiyah (ritual). Dalam kasus Ahmadiyah, misalnya, Himpunan Putusan Tarjih (HPT) dengan tegas menyatakan bahwa ayat dan hadis mengenai keberadaan Nabi Muhammad sebagai nabi terakhir sudah sangat jelas sehingga penolakan terhadap ayat dan hadis tersebut adalah pendustaan terhadap ayat dan hadis tersebut (Muhammadiyah, 2011, pp. 282-283). Hal itu menunjukkan sikap jelas dan tanpa kompromi dalam persoalan akidah.

Namun demikian, sikap tegas itu tidak dimaksudkan bagi legitimasi penggunaan cara-cara kekerasan, utamanya fisik, terhadap warga Ahmadiyah. Terlebih, sejarah mencatat adanya hubungan antara anggota Muhammadiyah dengan anggota Ahmadiyah pada awal perkembangan Ahmadiyah di Jawa (Zulkarnian, 2005). MTT Jawa Tengah, misalnya, pernah mengundang tokoh Ahmadiyah untuk berbicara di depan para ulama Majelis Tarjih PWM dan PDM se-Jawa Tengah untuk memberikan kesempatan kalangan Ahmadiyah untuk 
menjelaskan posisinya dalam persoalan kenabian Mirza Ghulam Ahmad yang menjadi polemik.

Hal demikian yang mungkin bisa dipandang sebagai posisi yang kurang sesuai untuk mendorong fikih hubungan antarumat beragama. Pada dasarnya terhadap isu-isu hubungan antarumat yang diangkat oleh Muhammadiyah, melalui MTT, lebih didasarkan atas keprihatinan warga Muhammadiyah terhadap berbagai isu sosial keagamaan. Namun, ada prinsip yang jelas yang diikuti oleh Muhammadiyah, yaitu meskipun secara gagasan Muhammadiyah tegas dalam kasus-kasus yang masuk kategori ibadah dan keyakinan, namun warga Muhammadiyah menghindari jalan-jalan kekerasan.

Terkait dengan kekerasan, MTT mempunyai sikap yang jelas. Hal itu bisa dilihat dalam putusan Musywil Tarjih Sukoharjo tanggal 21-22 November 2009. Putusan mengenai “Jihad dan Bom Bunuh Diri" menegaskan bahwa berdasarkan berbagai macam jihad, "meledakkan bom yang dengan sengaja menjadikan pelakunya mati termasuk bunuh diri, bukan istisyhad. Bunuh diri dengan alasan apapun menurut Islam haram hukumnya (Tengah, 2010, pp. 146147). Putusan ini menegaskan posisi Muhammadiyah Jawa Tengah terhadap klaim jihad yang dilakukan oleh sebagian kalangan umat Islam dengan melalui tindakan kekerasan sebagai tindakan yang tidak bisa diterima secara syar'i.

Persoalan kerukunan beragama yang mungkin menjadi isu penting penting adalah hubungan antara muslim dan nonmuslim. Beberapa isu mengenai hubungan antarumat beragama muncul dalam pembahasan tarjih. Di tingkat PW Jawa Tengah, misalnya, terdapat pembahasan mengenai menghadiri perayaan keagamaan umat agama lain, mengucapkan selamat hari Natal, dan mengucapkan salam, yaitu pada Musywil Tarjih di Purwokerto 2223 Maret 2008.

Musywil Tarjih Purwokerto tersebut melahirkan putusan MTT Muhammadiyah Jawa Tengah yang menegaskan bahwa menghadiri seremonial dan ritual agama lain (dengan kasus Natal) adalah haram bagi umat Islam. Dasar yang digunakan oleh MTT Jawa Tengah adalah: 1) Alquran, 2) sunah, 3) kaidah ushul, yaitu a) qiyas, b) sadd al-zariah, dan c) menolak mafsadah dilakukan atas menarik maslahah (در ألمفاسد مقدم على جلب المصالح), 4) kaidah fikih, yaitu a) bahaya harus dihilangkan, b) Melihat pada yang haram hukumnya juga haram, dan c) Jika halal dan haram tercampur, makan dimenangkan yang haram (اذا اجتمع الحلال و لحر ام غلب الحرام) (Tengah, 2010, pp. 168-171). Penggunaan berbagai kaidah atau pendekatan istinbath hukum tersebut merupakan terobosan penting di dalam tubuh Muhammadiyah yang kuat dengan semangat kembali kepada Alquran dan sunah.

Keanekaragaman dalil hukum dan kaidah istinbath itu memungkinkan lahirnya produk hukum yang berangkat dari pemeriksaan persoalan secara lebih detail. Dalam kasus mengucapkan selamat hari Natal, misalnya, berkembang pemikiran di kalangan musyawirin 
(peserta musyawarah tarjih) tentang perlunya tafshil (analisis) dalam melihat permasalahan. Muncullah gagasan analitis terhadap masalah, yaitu: 1) mengucapkan selamat atas Nabi Isa hukumnya sunah, 2) mengucapkan salam kepada Yahudi dan Nasrani hukumnya tidak boleh, dan 3) mengucapkan selamat Hari Natal hukumnya syubhat sehingga lebih baik dihindari (Tengah, 2010, pp. 178-180). Pendekatan analitis ini menunjukkan pendekatan yang tidak semata hitam putih dalam menyikapi pengucapan selamat Natal oleh umat Islam kepada umat Nasrani.

Meskipun pada dasarnya putusan MTT terhadap persoalan hubungan antarumat beragama dilandasi semangat protektif dengan menolak hal-hal yang dipandang masuk wilayah ubudiyah dan akidah agama lain, namun putusan tersebut tidak dibiarkan untuk mengarah kepada sikap eksklusif. Putusan Tarjih MTT PW Muhammadiyah Jawa Tengah menegaskan bahwa agama Islam tidak melarang umat Islam berhubungan dan berbuat baik serta berlaku adil kepada nonmuslim yang tidak memusuhi, dengan dasar surat al-Hujurat ayat 13, al-Mumtahanah ayat 8, al-Anfal ayat 61, dan Luqman ayat 15 (Tengah, 2010, pp. 180181).

Sebagian ulama Muhammadiyah bahkan membolehkan pejabat pemerintah dari tingkat pusat, kelurahan maupun pimpinan organisasi Islam, termasuk Muhammadiyah, untuk menghadiri seremonial Natal. Hal itu disampaikan oleh Yusuf Suyono, salah seorang pemakalah dalam Musywil Tarjih Purwokerto tersebut. Ia membolehkan untuk menghadiri perayaan Natal dengan catatan hati tetap teguh, dengan bersandar kepada kaidah fikih الضرورات تبيح المحظورات (keadaan darurat membolehkan hal-hal yang sebelumnya dilarang). Ia juga menambahkan bahwa negara Indonesia bukan negara Islam sehingga nonmuslim tidak berposisi sebagai ahl al-dzimmah. Hal itu, menurutnya, bisa menjadi illah untuk mengubah hal-hal yang dilarang menjadi boleh (Suyono, 2010, pp. 32-33).

Jadi, dinamika istinbath hukum mengenai hubungan antarumat beragama maupun internal agama yang dilakukan oleh MTT Muhammadiyah menunjukkan perkembangan metodologi yang memungkinkan lahirnya sikap-sikap moderat dalam hubungan antarumat beragama. Sikap tegas dalam masalah ubudiyah dan akidah tidakmenutup pintu bagikerjasama antarumat beragama. Dalam wilayah muamalah itulah, fikih moderat memiliki potensi untuk berkembang karena adanya Manhaj Tarjih MTT Muhammadiyah yang memungkinkan bagi perkembangan pemikiran hukum yang tidak semata-mata tekstual. Penggunaan dalil hukum alternatif, yang dalam ushul fiqh biasa dikenal dengan sebutan mukhtalaf, seperti sadd al-zariah dan maslahah menunjukkan bahwa orientasi tekstual yang kuat di kalangan Majelis Tarjih mengalami proses moderasi sehingga menerima pertimbangkan nontekstual. Penggunaan kaidah-kaidah fikih yang semakin luas di Majelis Tarjih menunjukkan bahwa analogi dan kaidah mulai mendapatkan tempat dalam penyelesian masalah hukum. Fenomena tersebut menjadi indikasi bagi perkembangan pemikiran hukum di kalangan 
Muhammadiyah yang semakin terbuka bagi tradisi pemikiran hukum Islam klasik. Proses tersebut tidak berarti menghilangkan pekerjaan rumah bagi warga Muhammadiyah untuk bisa mengakses yurisprudensi dalam khazanah fikih Islam klasik mengenai kasus-kasus hukum yang tidak lagi baru.

Dalam konteks hubungan antarumat beragama, Muhammadiyah harus menghadapi kenyataan bahwa keberadaannya mulai dipandang sebagai salah satu standar keislaman dan barometer bagi relasi antarumat beragama di Indonesia. Posisi itu sedikit banyak akan turut memengaruhi orientasi pemikiran hukum di Muhammadiyah. Terlebih, banyak warga Muhammadiyah yang menjadi aparatus negara atau akademisi yang harus berinteraksi dengan wacana kenegaraan.

\section{Kesimpulan}

Majelis Tarjih dan Tajdid Muhammadiyah, sebagai salah satu Majelis di Muhammadiyah dari tingkat Pimpinan Daerah sampai Pimpinan Pusat lahir dari upaya untuk memberikan jawaban atas perselisihan pendapat keagamaan yang muncul di kalangan warga. Meskipun awalnya bekerja untuk menarjih pendapat, pada perkembangannya MTT juga melahirkan putusan-putusan hukum Islam baru dalam kasus-kasus yang sedang hangat dihadapi oleh para warganya.

Persoalan hubungan antarumat beragama mendapatkan perhatian sejak awal lahirnya Muhammadiyah. Persoalan tersebut diambil dalam tulisan ini sebagai barometer dalam melihat perkembangan fikih moderat di Muhammadiyah. Dari beberapa putusan yang dihasilkan oleh Majelis Tarjih dan Tajdid Pusat dalam HPT maupun Majelis Tarjih dan Tajdid Pimpinan Wilayah Muhammadiyah Jawa Tengah. Sikap-sikap terhadap hubungan itu dalam putusan-putusan MTT masih cenderung defensif terhadap apa yang dipersepsi sebagai ancaman bagi keimanan. Persoalan akidah dan ibadah adalah dua persoalan yang dipandang penting oleh warga Muhammadiyah untuk tidak mengalami perubahan atau penyimpangan.

Pada kedua wilayah tersebut, sikap MTT Muhammadiyah cederung tegas, namun dengan moderasi berupa keterbukaan untuk kerjasama dalam bidang muamalah. Ketegasan dalam persoalan ubudiyah dan akidah tidak dimaksudkan sebagai pengesahan bagi penggunaan kekerasan sehingga aksi-aksi kekerasan antarumat beragama bukan menjadi pilihan warga Muhammadiyah. Itulah peran yang dimainkan oleh MTT Muhammadiyah dalam membangun cara pandang dan moderasi di kalangan warga Muhammadiyah.

Keterbukaan itu tidak lepas dari perkembangan metode yang dipergunakan di MTT sendiri. Pada perkembangannya, MTT menerima pendekatan yang lebih luas terhadap Alquran dan hadis, melalui penerimaan paradigma bayani dan burhani. Majelis Tarjih dan Tajdid Muhammadiyah juga membuka diri bagi penggunaan pendekatan intersidipliner 
dalam penyelesaian masalah hukum Islam, seperti pendekatan hermeneutik, sosiologi, sejarah, dan antropologi, dan penerimaan dalil hukum di luar nash, seperti sadd dzariah dan maslahah. Penggunaan yang semakin luas terhadap kaidah-kaidah fikih menunjukkan bahwa logika hukum Islam Muhammadiyah semakin terbuka terhadap khazanah pemikiran Islam klasik.

\section{Referensi}

Abdurrahman, A. (2004). Tarjih Muhammadiyah: Metodologi dan Aplikasi (III). Yogyakarta: Pustaka Pelajar.

Al-Baghawi, A. M. al-H. ibn M. (2002). Tafsir al-Baghawi (Ma’alim al-Tanzil). Beirut: Dar Ibn Hazm.

Al-Syafii, A. I. (2010). Al-Risalah (I). Beirut: Maktabah al-Ashriyyah.

Diklitbang, M. dan L. M. (2010). 1 Abad Muhammadiyah: Gagasan Pembaharuan Sosial Keagamaan. Jakarta: PT Kompas Media Nusantara.

Hidayat, S. (2010). Studi Kemuhammadiyahan: Kajian Historis, Ideologis, dan Organisasi. Surakarta: LPID Universitas Muhammadiyah Surakarta.

Imarah, M. (1988). Fundamentalisme dalam Perspektif Barat dan Islam. (A. H. Al-Kattani, Ed.). Jakarta: Gema Insani Press.

Manhaj Tarjih Muhammadiyah. (2014). Retrieved from httptarjih.muhammadiyah. or.idmuhfiletarjih downloadManhaj Tarjih Muhammadiyah.pdf

Muhammadiyah, P. P. (2011). Himpunan Putusan Tarjih Muhammadiyah. Yogyakarta: Suara Muhammadiyah.

Shihab, A. (1998). Membendung Arus: Respon Gerakan Muhammadiyah terhadap Penetrasi Misi Kristen di Indonesia. Bandung: Mizan.

Tengah, M. T. dan T. P. J. (2010). Kumpulan Putusan Tarjih Jawa Tengah. Semarang: MTT PW Muhammadiyah jawa Tengah dan Universitas Muhammadiyah Surakarta.

Zulkarnian, I. (2005). Gerakan Ahmadiyah di Indonesia. Yogyakarta: LkiS. 